\title{
45. TEMPERATURES OF FORMATION OF CALCITE VEINS IN THE BASALTS FROM DEEP SEA DRILLING PROJECT HOLES 417A AND 417D
}

\author{
James R. Lawrence, Lamont-Doherty Geological Observatory of Columbia University, Palisades, New York
}

The basalts recovered from Deep Sea Drilling Project Holes 417A and 417D, only one-half kilometer apart, show a sharp contrast in the degree of alteration. Hole $417 \mathrm{~A}$ basalts are highly altered to a variety of alteration minerals including celadonite, K-feldspar, hematite, smectite, calcite, and zeolites (Donnelly et al., 1977). Large amounts of potassium and phosphorus had to have been added and large amounts of calcium, magnesium, and sodium have been removed from the basalts (Donnelly, 1977). In contrast, Hole 417D basalts are very fresh. The explanation given for this difference was that Hole $417 \mathrm{~A}$ was drilled in a basement topograhic high (a volcanic hill) subjected to extensive weathering by a convecting fluid, probably sea water, before its eventual burial (Donnelly, 1977). In support of this explanation, it was noted that Hole 417D basalts, unlike Hole 417A basalts, were covered by Cretaceous sediments.

Calcite veins in the basalts of both sides were analyzed for ${ }^{18} \mathrm{O} /{ }^{16} \mathrm{O}$ and ${ }^{13} \mathrm{C} /{ }^{12} \mathrm{C}$ ratios in an attempt to determine their temperatures of formation and to verify that the fluid involved in the alteration process was sea water. The data are given in Table 1 . The oxygen isotope values in $\delta^{18} \mathrm{O}$ (SMOW) range from $+28.37 \%$ to $+30.6 \%$. These values are lower than those found in calcites from Leg $37\left(\delta^{18} \mathrm{O}\right.$ $=+32.6$ to $+34.8 \%$; ; Muehlenbachs, 1976) and from Leg $45\left(\delta^{18} \mathrm{O}=+30.6\right.$ to $+34.8 \%$; Lawrence et al., 1977) . The carbon isotope values in $\delta^{13} \mathrm{C}$ (PDB), -0.4 to $3.6 \%$, are comparable to those found on Legs 37 and 45 and are fully compatible with formation in sea water.

The temperatures of formation of the calcite veins have been calculated (Table 1) assuming that the fluid involved in the alteration process was sea water and that it had a $\delta^{18} \mathrm{O}=$ $0 \%$, that of deep ocean water. This assumption is reasonable considering that extensive metasomatism involving transport of very large amounts of sea water seems to have taken place in Hole 417A (Donnelly, 1977). The temperatures calculated for the calcites in both holes cover a similar range: $14^{\circ}$ to $41^{\circ} \mathrm{C}$. This range is distinctly higher than deep sea bottom water temperatures, even for the Cretaceous, which suggests, in agreement with the chemical budget studies of Donnelly (1977), that heated sea water flowed through these basalts during the alteration process. In view of the extent of metasomatism in the basalts of Hole 417A, the water flow probably must have been much higher in Hole $417 \mathrm{~A} \cdot{ }^{18} \mathrm{O} /{ }^{16} \mathrm{O}$ analyses across a single 6 to $8 \mathrm{~cm}$-thick calcite vein from Hole $417 \mathrm{~A}$ at a depth of 288 meters sub-
TABLE 1

Oxygen and Carbon Isotopic Composition of Calcite Veins, Holes 417A and 417D

\begin{tabular}{|c|c|c|c|c|}
\hline $\begin{array}{c}\text { Sample } \\
\text { (Interval in } \mathrm{cm} \text { ) }\end{array}$ & $\begin{array}{l}\text { Sub-Bottom } \\
\text { Depth } \\
\text { (m) }\end{array}$ & $\begin{array}{l}\delta 18 \mathrm{O} \\
(\mathrm{SMOW})\end{array}$ & $\begin{array}{l}\delta 13 \mathrm{C} \\
(\mathrm{PDB})\end{array}$ & $\begin{array}{c}\text { Temperature } \\
\text { of Formation }{ }^{\mathrm{a}} \\
\left({ }^{\circ} \mathrm{C}\right)\end{array}$ \\
\hline \multicolumn{5}{|l|}{ Hole 417A } \\
\hline $24-1,49-50$ & 218.0 & +28.8 & +1.6 & 22.6 \\
\hline $24-1,69-70$ & 218.2 & +29.0 & -0.4 & 21.5 \\
\hline $24-1,110-111$ & 218.5 & +28.6 & +0.7 & 23.7 \\
\hline $24-2,42-44$ & 219.4 & +29.1 & -0.8 & 21.2 \\
\hline $24-3,42-44$ & 220.9 & +29.3 & +2.3 & 20.2 \\
\hline $24-5,37-39$ & 223.9 & +29.7 & +3.2 & 18.7 \\
\hline $26-1,77-79$ & 237.3 & +29.4 & +2.0 & 20.1 \\
\hline $26-3,34-35$ & 239.9 & +29.7 & +2.7 & 18.4 \\
\hline $28-1,11-14$ & 255.6 & +29.0 & +2.2 & 21.6 \\
\hline $28-2,76-77$ & 257.8 & +29.4 & +2.0 & 20.0 \\
\hline $29-4,117-118$ & 271.7 & +28.9 & +2.0 & 22.1 \\
\hline $31-2,115-118$ & 286.7 & +28.8 & +0.9 & 22.5 \\
\hline $31-3,91-93$ & 288.0 & +27.0 & +1.4 & 31.0 \\
\hline $31-3,93-95$ & 288.0 & +28.5 & +1.8 & 23.8 \\
\hline $31-3,95-97$ & 288.0 & +28.3 & +1.6 & 34.8 \\
\hline $32-2,115-117$ & 296.2 & +28.8 & +0.9 & 22.5 \\
\hline $32-4,16-17$ & 298.2 & +28.2 & +1.8 & 25.2 \\
\hline $34-6,72-74$ & 320.5 & +28.0 & +2.7 & 26.2 \\
\hline $36-6,67-69$ & 340.2 & +27.7 & +2.6 & 27.8 \\
\hline $38-1,67-68$ & 349.2 & +27.4 & +2.7 & 29.1 \\
\hline $38-2,59-61$ & 350.6 & +27.0 & +1.4 & 31.0 \\
\hline $38-5,18-19$ & 354.7 & +27.4 & +2.9 & 28.9 \\
\hline $41-2,46-48$ & 371.5 & +28.1 & +2.0 & 25.7 \\
\hline $41-4,87-89$ & 374.9 & +26.5 & +0.5 & 33.5 \\
\hline $41-6,26-28$ & 377.3 & +30.3 & +1.8 & 16.1 \\
\hline $42-3,126-127$ & 383.3 & +29.8 & +1.8 & 18.2 \\
\hline $44-2,46-47$ & 396.5 & +30.6 & +1.5 & 14.6 \\
\hline $44-3,145-147$ & 399.0 & +30.6 & +1.4 & 14.6 \\
\hline $46-1,90-92$ & 399.7 & +29.0 & +1.5 & 21.6 \\
\hline $46-1,95-97$ & 399.7 & +29.6 & +1.5 & 19.1 \\
\hline $46-2,44-46$ & 400.7 & +29.9 & +1.8 & 17.9 \\
\hline $46-3,13-14$ & 402.0 & +29.6 & +1.7 & 19.0 \\
\hline \multicolumn{5}{|l|}{ Hole 417D } \\
\hline $22-1,130-131$ & 345.3 & +30.6 & +2.5 & 14.9 \\
\hline $22-3,50-51$ & 347.5 & +29.7 & +1.7 & 18.7 \\
\hline $22-5,87-89$ & 350.9 & +29.2 & +1.0 & 20.7 \\
\hline $26-4,18-19$ & 361.2 & +29.4 & +0.7 & 20.1 \\
\hline $28-3,78-79$ & 379.5 & +29.7 & +1.6 & 18.7 \\
\hline $31-3,45-46$ & 403.5 & +29.9 & +2.5 & 17.9 \\
\hline $33-3,55-56$ & 424.7 & +30.6 & +3.6 & 14.9 \\
\hline $36-4,11-13$ & 450.1 & +26.2 & +1.6 & 35.2 \\
\hline $39-4,40-41$ & 379.5 & +29.7 & +2.0 & 21.7 \\
\hline $42-3,16-17$ & 487.9 & +27.6 & -0.2 & 27.9 \\
\hline $45-1,122-123$ & 514.7 & +25.1 & +1.4 & 41.2 \\
\hline
\end{tabular}

${ }^{a}$ The calcite-water temperature relationship of O'Neil et al. (1969) was used, assuming the $\delta{ }^{18} \mathrm{O}$ of the water was $0 \%$ (SMOW). 
bottom suggest progressive formation of the calcite veins at decreasing temperatures. The edges of the vein in contact with the basalt were formed at $31.0^{\circ}$ and $34.8^{\circ}$, whereas its center was formed at $23.8^{\circ} \mathrm{C}$.

\section{ACKNOWLEDGMENTS}

Financial support for this research came from National Science Foundation Grant OCE-77-81952.

\section{REFERENCES}

Donnelly, T. W., 1977. The chemical budget of alteration at 417A - a preliminary estimate, EOS, Trans. Am. Geophys. Union, v. 58, p. 1174 .

Donnelly, T. W., Francheteau, J., Salisbury, M., Kelts, K., Swift, S. A., Borella, P. E., Bleil, U., Smith, B. M., Juteau,
T., Rusinov, V., Sinton, J. M., Ui, T., Orr, W. N., and Gartner, S., 1977. Mid-ocean ridge in the Cretaceous, Geotimes, v. 22, p. 21-23.

Lawrence, J. R., Drever, J. I., and Kastner, M., 1977. Low temperature alteration of the basalts predominates at Site 395 of the Deep Sea Drilling Project. Proc. Second. Internat. Symp. on Water-Rock Interaction, Strasbourg, France, p. 1-355 to 1-362.

Muehlenbachs, K., 1976. Oxygen isotope geochemistry of DSDP Leg 37 rocks. In Aumento, F., Melson, W. G., et al., Initial Reports of the Deep Sea Drilling Project, v. 37: Washington (U.S. Government Printing Office), p. 617-620.

O'Neil, J. R., Clayton, R. N., and Mayeda, T., 1969. Oxygen isotope fractionation on divalent metal carbonates, J. Chem. Phys., v. 51, p. 5547. 